\title{
Pregnancy Education Can Reduce Stress and Mothers Remain Fit an Delivery During The Covid-19 Pandemic
}

\author{
Iceu Amira ${ }^{a)}$, Hendrawati, Sukma Senjaya, and Indra Maulana \\ Nursing Faculty, Universitas Padjadjaran Bandung, Jawa Barat, Indonesia \\ a)Corresponding author: amira@unpad.ac.id
}

\begin{abstract}
Pain in labor can cause blood pressure to increase which causes stress and disrupted labor, this can certainly hamper labor so that the delivery time will be longer. The purpose of the activity is to increase knowledge and understanding of pregnancy exercise which can reduce stress so that delivery runs smoothly during the covid-19 pandemic. The method used is webinar via zoom, question and answer and demonstration and poster distribution. The results of the health webinar activity are named "Pregnancy Gymnastics Education Can Reduce Stress and Mothers Stay Fit During Delivery During Covid-19". which will be held on Sunday, April 25, 2021, starting at 09.00 to 12.00. In the process of conducting the webinar; The participants looked very enthusiastic when the material was given. Participants participated in the webinar enthusiastically even though it was conducted online. The webinar activity was conducive because the participants paid attention to the material presented well and asked questions.
\end{abstract}

Keywords: fit mother, pregnancy exercise, webinars, online

\section{INTRODUCTION}

The process of giving birth is always something scary for pregnant women. Especially if the tense moment is still the first experience in his life. Mental preparation, physical health, family support and last but not least adequate health facilities are necessary for the smooth delivery process. Not to mention in the midst of the current Covid-19 pandemic, the risks of childbirth are increasingly vulnerable. This can make pregnant women confused and stressed. However, you should not need to worry, because stress conditions actually affect the immune system of the Pregnance Women. The thing that must be considered is to apply preventive action procedures until the delivery process is complete.

Childbirth is the process of expelling the products of conception from the womb to the outside world (Wijayanti, 2018) The most common thing that occurs in labor is pain. Pain in labor is something normal if it is still within reasonable limits and can be tolerated by the mother. Pain is a complex and unpleasant condition that involves sensory and emotional components (Trianingsih, 2019).

According to research (Fitri et al., 2019) Pain occurs in most deliveries, which is $90 \%$ of deliveries. Pain that occurs can occur from the beginning of labor until complete dilatation in about 12-18 hours, this of course can torture the mother if the pain caused cannot be tolerated (Trianingsih, 2019). According to Mander (2004) in Fitri et al. (2019) Pain in labor can cause blood pressure to increase which causes stress and disrupted labor, this can certainly hamper labor so that the delivery time will be longer.

In addition, what often happens to mothers who are about to give birth is anxiety because pregnant women are worried about their ability to go through the labor process. Continuous anxiety will interfere with uterine contractions which play an important role in the course of labor (Yanuarita et al., 2017)

Various ways are done to help facilitate labor, either through pharmacological therapy or nonpharmacological therapy. Pharmacological therapy is more effective in assisting childbirth but is 
more expensive and has the potential to have adverse effects, both for the mother and the fetus. Meanwhile, pharmacological therapy is cheaper and has no side effects and can lead to maternal satisfaction due to the success of the therapy (Biswan et al., 2017).

One of the non-pharmacological therapies that can be done is pregnancy exercise. Pregnancy exercise is a physical and mental relaxation that can stabilize the mother's emotions. Pregnancy exercise is one of the activities during pregnancy or prenatal care that aims to strengthen contractions and maintain flexibility of the abdominal wall muscles, ligaments, and pelvic floor muscles in optimizing preparation for normal delivery (Suryani \& Handayani, 2018). In a study conducted by Yanuarita, Djuwantono, Sedjati, Husin, \& Susanto (2017) it was found that pregnancy exercise can reduce anxiety levels that affect smooth labor so that the active phase until the birth of the baby can be reached in 10 hours. In addition, it was also found that pregnancy exercise can reduce the degree of perineal tear to $<2$ and the degree of asphyxia up to $97 \%$ (Yanuarita et al., 2017). The purpose of PKM activities is to increase knowledge and understanding of pregnancy exercise, so that delivery goes smoothly

\section{MATERIALS AND METHODS}

The number of participants who registered in the registration form for Health Education activities through the WEBINAR "Mothers in Smooth Delivery with Pregnancy Exercises" were 62 people and 40 people who attended the zoom meeting. Of all participants who attended the zoom meeting room, only 38 people filled out the questionnaire. pretest and 33 people filled out the posttest. The extension method by means of webinars or through online can understand the content of the material presented as a science. This method is given together with the power point of the material.

By conducting discussions, the participants were able to solve the problems faced from the questions given by other participants with the topic of the material discussion. The discussion method also aims to exchange ideas, thoughts, information/experiences among participants, so that an agreement is reached on the main ideas.

\section{RESULT}

This webinar is held with the aim of increasing the knowledge and insight of the general public regarding the management of pregnancy exercise which is very useful as an alternative therapy to deal with stress during pregnancy and childbirth and to overcome the complaints felt during pregnancy so that later the knowledge provided in this health education webinar can be useful. either the mother, the mother-to-be or the wider community. This webinar will be held on Sunday, April 25, 2021, from 08.15 to 12.00 online. The webinar was attended by 40 participants with a total of 62 participants who registered.

The event started by filling out the pretest first as an overview of initial knowledge and attendance was continued by introducing the presenters. After introducing the presenters, the moderator invited the presenters to start the main activity, namely lectures and demonstrations related to pregnancy exercise. The material lecture this time was carried out using PPT media and demonstrations were carried out with video media. The participants participated in the activity enthusiastically during the activity, which was shown by the number of questions that entered the chat column during the event. When showing the demonstration video, the participants were quite enthusiastic, there were several participants who took part in the pregnancy exercise demonstration and some of them were mothers who were pregnant with their first child. After the material session was delivered, the moderator directed the participants to a question and answer session, because there were quite a lot of questions, the moderator first limited to 3 questions but 
after coordinating with the other committees, it turned out that there was still a lot of time left so that 7 questions were answered completely by the team.

After the speaker finished, he entered the post-test filling session, the results showed an increase in knowledge from pre-test to post-test. In addition, the committee provides door prizes as a form of appreciation to participants with the best and fastest questions and to participants with the highest post-test scores.

\section{DISCUSSION}

Based on McQuail's theory, participants in this health promotion belong to the Specialized audience type, that is, participants come from the general public from wherever they are. Although they do not know each other, are scattered and heterogeneous in several ways such as age, education level, income, lifestyle and so on, they have one common interest which is related to pregnancy exercise. Participants know that this activity comes from promotional media that the committee does through social media Whatsapp or Instagram.

Then participants are required to fill out a Google form as a registration requirement. The target participants for this activity are women, especially women who are pregnant and currently or about to get married. So that it is expected to apply pregnancy exercises in accordance with the right procedures.

In the process of implementing this webinar, the participants seemed enthusiastic when the material was given. Participants participated in this webinar with enthusiasm, even though the implementation was online, especially when there was a pregnancy exercise demonstration which was also attended by participants who were pregnant.

Based on the results of the pretest, the average result was 63.16 with a score distribution of 1 person getting a score of 0,9 people getting a score of 40 , then 13 people getting a score of 60 , 12 people getting a score of 80 and 3 people getting a score of 100 . The total number of participants who filled out 38 people. so it can be concluded that the health education is needed in order to increase the knowledge of participants related to pregnancy exercise. The health education carried out can be categorized as successful, it can be seen based on the average posttest score of the participants which has increased to 81.82 from the pretest score of 63.16. The total number of participants who filled out the posttest was 33 people with a score distribution of 1 getting a score of 40,7 people getting a score of 60 , then 13 people getting a score of 80 and 12 people getting a score of 100 .

\section{CONCLUSION}

This webinar activity is held once a year with the aim of increasing public knowledge, especially about mental health, which on this occasion is about pregnancy exercise and stress during pregnancy and childbirth. In fact, not all pregnant women do pregnancy exercises because of limited knowledge or lack of motivation from themselves or from others. By holding this webinar, the public will understand what pregnant women should do to facilitate their delivery.

\section{REFERENCES}

Biswan, M., Novita, H., \& Masita. (2017). Efek Metode Non Farmakologik terhadap Intensitas Nyeri. Jurnal Kesehatan, VIII(2), 282-288.

Fitri, L., Nova, S., \& Nurbaya, R. (2019). Hubungan Teknik Nafas Dalam Terhadap Pengurangan Intensitas Nyeri Kala I Fase Aktif di Klinik Pratama Jambu Mawar. Jurnal Endurance, 4(2), 419. https://doi.org/10.22216/jen.v4i2.4122

Trianingsih, I. (2019). Pengaruh Murotal Al Qur'an dan Dzikir terhadap Intensitas Nyeri Kala I Persalinan. Jurnal Ilmiah Keperawatan Sai Betik, 15(1), 26. https://doi.org/10.26630/jkep.v15i1.1283 
Wijayanti, D. T. (2018). Hubungan Sectio Caesarea Dengan Kejadian Asfiksia Di Rumah Sakit Umum Daerah (Rsud) Syarifah Ambami Rato Ebu Bangkalan. J-HESTECH (Journal Of Health Educational Science And Technology), 1(1), 9. https://doi.org/10.25139/htc.v1i1.1066

Yanuarita, S. P., Djuwantono, T., Sedjati, A., Husin, F., \& Susanto, H. (2017). Penerapan Senam Selama Hamil dan Efektifitasnya Terhadap Lama Persalinan, Robekan Perineum dan Hasil Luaran Bayi. Jurnal Pendidikan Dan Pelayanan Kebidanan Indonesia, 3(2), 56. https://doi.org/10.24198/ijemc.v3i2.48 


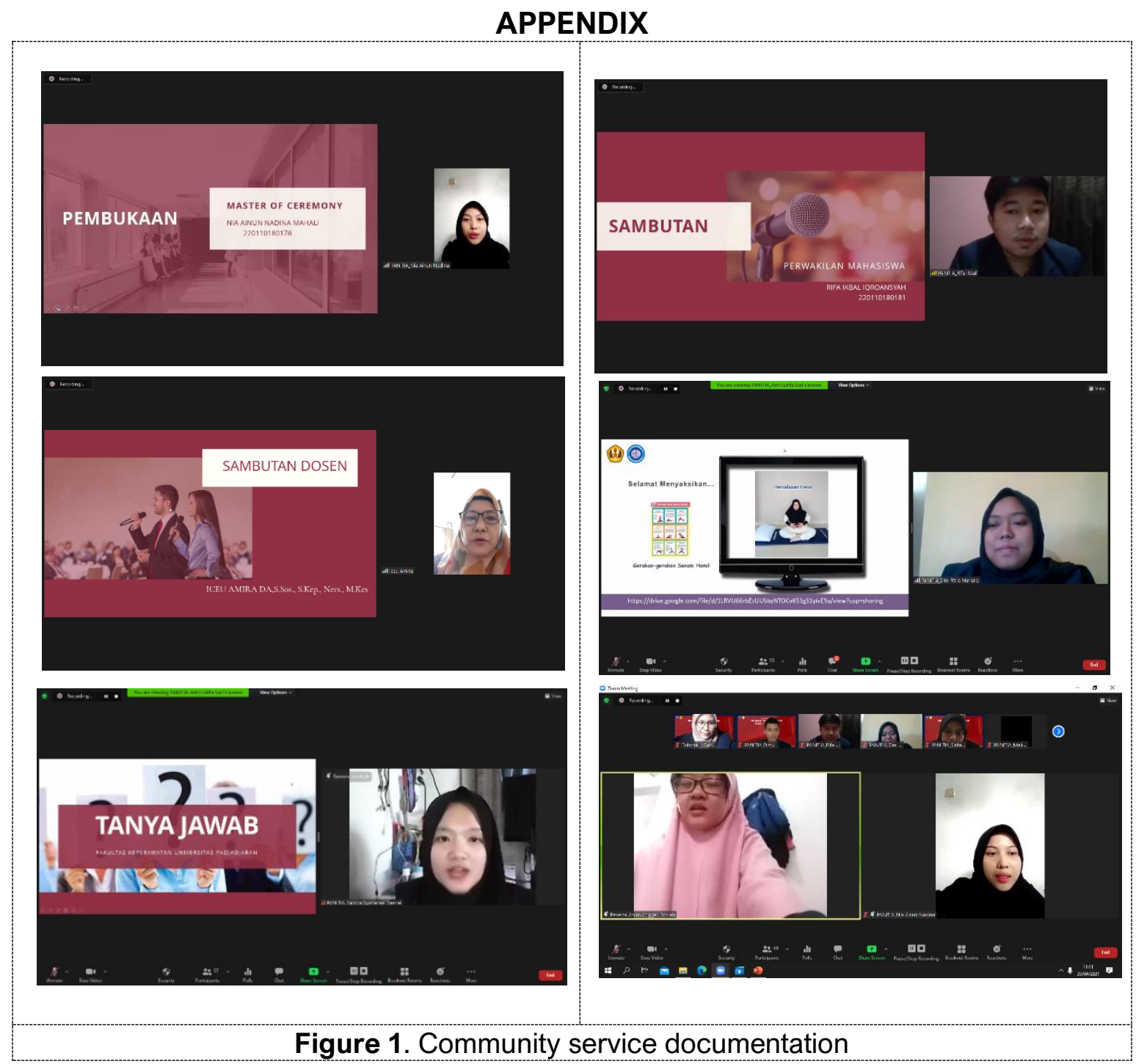

